\title{
PENAPISAN DAN IDENTIFIKASI BAKTERI LIPOLITIK YANG DIISOLASI DARI AIR LIMBAH PENGOLAHAN SURIMI DAN PENGALENGAN RAJUNGAN
}

\section{Screening and Identification of Lipolytic Bacteria Isolated From Surimi Processing and Crab Canning Wastewater}

\author{
Devi Ambarwaty Oktavia* dan Singgih Wibowo \\ Pusat Penelitian dan Pengembangan Daya Saing Produk dan Bioteknologi Kelautan dan Perikanan, \\ JI. KS Tubun Petamburan VI Slipi Jakarta Pusat Indonesia \\ * Korespondensi Penulis: devi_oktav@yahoo.co.uk
}

Diterima: 28 Juni 2016; Disetujui: 30 Oktober 2016

\begin{abstract}
ABSTRAK
Industri pengolahan hasil perikanan di sepanjang pantai Utara Jawa seperti pengalengan rajungan di Cirebon (Jawa Barat) dan pengolahan surimi di Kendal (Jawa Tengah), menghasilkan air limbah yang mengandung banyak protein dan lemak. Bakteri yang hidup di limbah yang banyak mengandung protein dan lemak tersebut diperkirakan memiliki kemampuan untuk menghidrolisis lemak menjadi asam lemak dan gliserol sehingga berpotensi untuk dimanfaatkan sebagai bioremedian alami bagi penanganan air limbah hasil perikanan di tempat lain. Penelitian ini bertujuan untuk melakukan penapisan dan identifikasi bakteri lipolitik potensial sebagai bioremedian air limbah perikanan. Penapisan dilakukan terhadap 11 isolat bakteri lipolitik dari air limbah yang diambil dari industri pengalengan rajungan di Cirebon dan pengolahan surimi di Kendal dengan menggunakan media spesifik agar tributirin. Isolat bakteri lipolitik potensial ditentukan berdasarkan zona bening yang terbentuk di sekitar koloni, yaitu sekurang-kurangnya $6 \mathrm{~mm}$. Isolat bakteri potensial ini selanjutnya diidentifikasi secara molekuler berdasarkan analisis sekuen 16S-rDNA. Dari penapisan diperoleh empat isolat bakteri potensial, yaitu isolat SPB, SHj, SOr dan SKn. Identifikasi molekuler menunjukkan bahwa isolat SPB dan SHj masing-masing adalah Serratia fonticola 10A dan Bacillus cereus strain 103.2.2 dengan kemiripan 97\%, isolat SOr memiliki kemiripan $96 \%$ dengan Bacillus pumilus strain vit bac1 dan isolat SKn adalah Enterococcus pseudoavium strain L3C21K2 dengan kemiripan 87\%. Keempat isolat tersebut berpotensi untuk dimanfaatkan sebagai bioremedian pada air limbah dari industri pengolahan hasil perikanan di Indonesia.
\end{abstract}

KATA KUNCI : penapisan bakteri lipolitik, air limbah industri perikanan, identifikasi bakteri

\begin{abstract}
Fish processing industries in Northern Coastal of Java, such as crab canning in Cirebon (West Java) and surimi processing in Kendal (Central Java), disposed huge of waste water containing high protein and fat. Lipolytic bacteria grown in the waste water could hydrolyze lipids into fatty acids and glycerol which are potential for bioremediants for fish industries waste water treatment in other area. The aim of this research is to screen and identify potential lipolytic bacteria as bioremediant for fisheries waste water. Screening has been done on 11 lipolytic bacteria isolated from waste water of crab canning in Cirebon and surimi processing in Kendal using tributyrin agar as selective media. The potential lipolytic bacteria isolates were determined based on diameter of clear zone formed, at least $6 \mathrm{~mm}$ around the colony. These isolates were selected and identified using 16S-rDNA sequencing. From the screening, four potential bacteria were found, i.e SPB, SHj, SOr and SKn isolates. Molecular identification showed that the SPB and SHj isolates were identified as Serratia fonticola $10 \mathrm{~A}$ and Bacillus cereus strain 103.2 .2 respectively, with $97 \%$ similarity, the SOr isolate has $96 \%$ similarity with Bacillus pumilus strain vit bac1 and the the SKn isolate has $87 \%$ similarity with Enterococcus pseudoavium strain L3C21K2. Those four isolates are potential for bioremediant for wastewater treatment in other industrial fisheries processing in Indonesia.
\end{abstract}

Keywords : screening of lipolytic bacteria, fisheries waste water, bacteria identification 


\section{PENDAHULUAN}

Air limbah yang dihasilkan dari proses pengolahan hasil perikanan mempunyai kandungan bahan organik seperti lemak dan protein, sehingga memiliki BOD (biological oxygen demand) yang tinggi. Selama ini penanganan terhadap air limbah dari usaha pengolahan ikan skala UKM masih dilakukan secara fisik dan dibuang ke badan air. Beberapa usaha pengolahan ikan skala yang lebih besar sudah mulai menggunakan instalasi pengolahan air limbahnya dengan memanfaatkan bakteri komersial. Penanganan air limbah pengolahan surimi di Kendal mengolah limbah cairnya melalui IPAL dengan kapasitas 200 ton per hari dan biaya yang dikeluarkan sebesar 55 juta per bulan (Fajar, komunikasi pribadi, 2011). Tay, Show dan Hung (2006) melaporkan pengolahan hasil perikanan pada umumnya menghasilkan air limbah dengan BOD sebesar 1-72,5 kg untuk setiap ton produk yang dihasilkan, sedangkan pengolahan filet ikan menghasilkan air limbah dengan BOD sebesar 12,5$37,5 \mathrm{~kg}$ per ton filet. Tingginya BOD pada air limbah tersebut terutama akibat protein yang tercuci selama proses pembersihan dan darah ikan yang terbuang bersama air limbah. Selain protein, lemak juga merupakan kontaminan yang relatif besar pada air limbah perikanan. Lemak (termasuk minyak) merupakan parameter penting yang ada pada air limbah pengolahan hasil perikanan. Komponen ini besarnya bervariasi mulai dari 0 hingga $20.000 \mathrm{mg} / \mathrm{L}$ tergantung jenis ikan dan proses yang digunakan (Colic, Morse, Hicks, Lechter \& Miller, 2011; Tay et al., 2006).

Beberapa jenis usaha industri kecil di Tegal seperti fillet ikan, tepung ikan serta usaha kecil lainnya yaitu industri kecap, dan saos mempunyai kendala dalam pengelolaan limbahnya. Hal ini dikarenakan minimnya pengetahuan tentang lingkungan, kurangnya kesadaran untuk menjaga lingkungan, kurangnya modal usaha dan biaya pelestarian lingkungan dan informasi tentang teknologi lingkungan yang murah dan efisien (Setiyono \& Wahjono, 2006). Hasil penelitian terdahulu (Oktavia \& Wibowo, 2012) menginfomasikan bahwa air limbah pengolahan pengalengan rajungan di Cirebon menghasilkan limbah cair dengan kandungan TDS $4310 \mathrm{mg} / \mathrm{L}$, sulfida 0,21 $\mathrm{mg} / \mathrm{L}, \mathrm{BOD}_{5} 270 \mathrm{mg} / \mathrm{L}$ dan COD (chemical oxygen demand) $410 \mathrm{mg} / \mathrm{L}$, sedangkan air limbah pengolahan surimi di Pekalongan menghasilkan limbah cair dengan kandungan sulfida sebesar $0,15 \mathrm{mg} / \mathrm{L}, \mathrm{BOD}_{5} 1100 \mathrm{mg} / \mathrm{L}$, COD $1650 \mathrm{mg} / \mathrm{L}$ dan lemak sebesar 39,6 mg/L. Selain di Tegal, industri pengolahan ikan yang berkembang secara alami adalah Muncar Kabupaten Banyuwangi. Kapasitas produksi industri kecil di Muncar yaitu tepung ikan 80 ton/hari, minyak ikan 23.400 ton/hari dan pemindangan ikan 100 ton/hari, sedangkan kapasitas produksi industri skala besar yaitu 1.209 ton/hari untuk industri pengalengan ikan, tepung ikan, minyak ikan, cold storage dan pengolahan ikan lainnya. Potensi jumlah limbah yang dihasilkan dikelompokkan menjadi dua yaitu air limbah produksi dan air limbah domestik. Aktifitas produksi seperti pencucian komponen-komponen peralatan dan lantai produksi yang sesuai dengan jenis kegiatan industrinya menghasilkan air limbah produksi, sedangkan air limbah domestik berasal dari kamar mandi, toilet, kantin, wastafel dan tempat wudhu. Total air limbah yang dihasilkan dapat mencapai 14.266 $\mathrm{m}^{3} /$ hari. Industri tepung ikan menghasilkan limbah cair dengan $\mathrm{BOD}_{5}$ sebesar $707 \mathrm{mg} / \mathrm{L}, \mathrm{COD}$ sebesar 1700 $\mathrm{mg} / \mathrm{L}$ dan minyak lemak $8,54 \mathrm{mg} / \mathrm{L}$. Industri pengalengan ikan menghasilkan limbah cair dengan kandungan $\mathrm{BOD}_{5}$ sebesar $689 \mathrm{mg} / \mathrm{L}, \mathrm{COD} 1500 \mathrm{mg} / \mathrm{L}$ dan minyak sebesar $6,54 \mathrm{mg} / \mathrm{L}$ (Setiyono \& Yudo, 2008).

Upaya untuk mereduksi bahan organik yang terakumulasi di perairan atau limbah pengolahan hasil perikanan perlu dilakukan sehingga potensi untuk mencemari lingkungan dapat dikurangi atau bahkan dihindari. Pendekatan yang paling efektif adalah melalui bioremediasi yang merupakan proses pembersihan lingkungan dari bahan-bahan pencemar secara biologis, terutama mikroorganisme. Pencemaran tersebut dapat berasal dari buangan pengolahan hasil perikanan, pakan, atau bahan lain sehingga bahan organik yang terakumulasi bersifat kompleks.

Pemanfaatan bakteri untuk mendegradasi bahan organik seperti protein dan lemak yang ada pada air limbah dari pengolahan hasil perikanan sudah banyak dilakukan di antaranya dengan menggunakan bakteri yang diisolasi dari lingkungan yang serupa, baik dalam bentuk kultur tunggal maupun campuran (Bhumibhamon, Koprasertsak \& Funthong, 2002). Pendekatan ini dinilai cukup efisien dalam mendegradasi lemak dari air limbah. Bakteri lipolitik yang menghasilkan enzim lipase diperlukan untuk mendegradasi lemak pada air limbah. Pemanfaatan bakteri lipolitik ini dapat mengeliminasi proses pretreatment air limbah, atau sekurang-kurangnya mengurangi beban pada proses pretreatment pada proses pengolahan limbah. Sebagai contoh, dalam skala laboratorium Bacillus cereus N-09 dapat digunakan untuk menurunkan lemak pada kuah mie instan cair hingga $73,5 \%$ pada suhu $30^{\circ} \mathrm{C}, \mathrm{pH} 6$ dengan kecepatan agitasi $130 \mathrm{rpm}$ (Hidayat, 2011). Penelitian lain (Loperena et al., 2009) memanfaatkan Pseudomonas sp. dan Bacillus sp. dari air limbah pengolahan susu yang bekerja lebih baik daripada inokulum komersial dalam mereduksi protein $(93 \%$ dibandingkan $54 \%$ ) dan lemak (72\% dibandingkan 
$38 \%$ ) pada air limbah pengolahan susu, namun menurunkan COD (57\% dibandingkan 63\%) lebih kecil daripada inokulum komersial.

Pengolahan air limbah dari pengolahan hasil perikanan dengan penambahan konsorsium bakteri dan perlakuan pemanasan menggunakan otoklaf mampu menurunkan kadar protein total sebesar $36,11 \%$ dan kadar lemak sebesar $34 \%$ pada air limbah pengalengan rajungan Desa Gebang Mekar Cirebon dan pengolahan surimi Pekalongan (Oktavia \& Wibowo, 2012). Namun demikian, masing-masing bakteri dari konsorsium tersebut belum teridentifikasi karakteristiknya. Sebagaimana air limbah pengolahan surimi di Pekalongan, air limbah pengolahan surimi di Kendal mempunyai kandungan lemak cukup tinggi pula yaitu sebesar $100 \mathrm{mg} / \mathrm{L}$ (Oktavia, 2011). Dari air limbah ini, diduga dapat diperoleh isolat-isolat bakteri pendegradasi lemak (lipolitik) sebagai bioremedian bagi air limbah tersebut atau lingkungan lain yang serupa. Penelitian ini dimaksudkan untuk melakukan penapisan serta mengidentifikasi bakteri lipolitik dari air limbah industri pengolahan surimi di Kendal (Jawa Tengah) dan pengolahan pengalengan rajungan di Cirebon (Jawa Barat).

\section{BAHAN DAN METODE}

\section{Bahan}

Dalam penelitian ini digunakan air limbah industri pengolahan hasil perikanan yang diambil secara langsung dari dua lokasi, yaitu pengalengan rajungan di Cirebon (Jawa Barat) dan pengolahan surimi di Kendal (Jawa Tengah). Sampel diambil dengan menggunakan botol steril volume $500 \mathrm{ml}$. Air limbah diambil pada bagian outlet unit pengolahan ikan yang belum mengalami perlakuan atau pretreatment. Sampel dimasukkan ke dalam cool box berisi hancuran es, lalu dibawa ke Laboratorium Pusat Penelitian dan Pengembangan Daya Saing Produk dan Bioteknologi Kelautan dan Perikanan (P3DSPBKP) Jakarta. Bahan lain yang digunakan adalah media pertumbuhan mikroba (nutrient agar, Oxoid); media nutrient broth (Oxoid); media selektif untuk pertumbuhan bakteri penghasil lipase tributyrin agar (TBA, Sigma Aldrich) dengan komposisi 5\% pepton; $3 \%$ ekstrak khamir, $12 \%$ agar; tributirin netral atau gliserol tributirat sebanyak $10 \mathrm{ml} / \mathrm{iter}$, dan bahanbahan lain untuk mengidentifikasi isolat bakteri.

\section{Metode}

\section{Penapisan bakteri lipolitik}

Media spesifik yang digunakan untuk penapisan bakteri penghasil lipase adalah agar tributirin (Ankit, Yaginik, Pranali \& Yadav, 2011; Prasad \& Manjunath,
2011; Sirisha, Rajasekar \& Narasu, 2010). Air limbah pengalengan rajungan dan pengolahan surimi masingmasing sebanyak $0,1 \mathrm{ml}$ diinokulasikan ke dalam media padat nutrient agar (NA), kemudian diinkubasi pada suhu $30^{\circ} \mathrm{C}$ selama $48 \mathrm{jam}$. Koloni yang tumbuh dipindahkan pada media padat tributirin, dengan cara menggoreskan 1 ose dari setiap koloni di medium NA, disebar di atas medium TBA dan diinkubasi selama 48 jam. Dari setiap koloni tunggal yang tumbuh, kemudian diambil 1 ujung ose steril dan ditotol di atas medium TBA lalu diinkubasi pada suhu $30^{\circ} \mathrm{C}$ selama 48 jam. Terhadap koloni bakteri yang menghasilkan zona bening kemudian dilakukan pengamatan morfologi koloni yang meliputi bentuk, warna dan diameter koloni (Sirisha et al., 2010).

Koloni yang tumbuh di atas media selektif agar tributirin dan membentuk zona bening di sekitar koloni merupakan bakteri pendegradasi lemak. Koloni yang mempunyai zona bening lebih dari $6 \mathrm{~mm}$ di sekitar koloni adalah yang dipilih untuk diidentifikasi (Ankit et al., 2011; Darmayasa, 2008). Pengukuran diameter zona bening dilakukan dengan cara membagi diameter zona bening dengan diameter koloni bakteri. Diameter zona bening diukur 2-4 kali dengan memasukkan pengukuran diameter zona bening terpendek dan terjauh. Perbandingan diameter zona bening di sekeliling koloni dengan diameter koloni merupakan Indeks Lipolitik (Renjana, Ni'matuzahroh \& Sumarsih, 2012; Wahyuntari, Mubarik \& Anggarani, 2004). Penentuan nilai Indeks Lipolitik adalah sebagai berikut :

Indeks Lipolitik : $\frac{\text { diameter zona bening }(\mathrm{mm})}{\text { diameter koloni }(\mathrm{mm})}$

Isolat dengan nilai indeks lipolitik besar diasumsikan mempunyai aktivitas lipolitik yang tinggi.

\section{Penentuan kurva pertumbuhan}

Penentuan kurva pertumbuhan terhadap bakteri dilakukan untuk mengetahui saat optimum bakteri digunakan sebagai starter bioremedian, yaitu ketika bakteri berada pada fase logaritmik. Kultivasi dilakukan menurut Mongkolthanaruk dan Dharmsthiti (2002) yang telah dimodifikasi yaitu dengan menggantikan kecepatan dan suhu shaker incubator dari $200 \mathrm{rpm}$ pada $15^{\circ} \mathrm{C}$ menjadi $100 \mathrm{rpm}$ pada $30^{\circ} \mathrm{C}$ sesuai dengan kondisi lingkungan. Sebanyak 1 loop bakteri dari koloni terpilih diinokulasikan ke dalam 100 $\mathrm{ml}$ media nutrient broth (NB). Inkubasi dilakukan menggunakan shaker incubator kecepatan $100 \mathrm{rpm}$ dan suhu $30^{\circ} \mathrm{C}$ selama 48 jam. Kurva pertumbuhan bakteri ditentukan dengan mengukur (optical densityl 
OD) pada panjang gelombang $600 \mathrm{~nm}$ menggunakan spektrofotometer, setiap 2 jam hingga 48 jam.

\section{Identifikasi bakteri secara molekuler}

Identifikasi bakteri dilakukan secara molekuler berdasarkan sekuen gen penyandi 16S-rRNA (Suwanto, Yogiara, Suryanto, Tan \& Puspitasari, 2000) menggunakan PCR yang dibandingkan dengan data sekuen yang tersedia di GenBank (BLAST, 2016). Tahap-tahap analisis identifikasi secara molekuler meliputi a) isolasi DNA total; b) amplifikasi gen penyandi $16 S-r R N A$ dengan PCR; $c$ ) verifikasi dengan elektroforesis gel agarosa; d) ekstraksi DNA dari agarosa; e) cycle sequencing; f) purifikasi hasil PCR dan g) sequencing hasil PCR. Analisis hasil sekuensing dilakukan dengan menggunakan metode dalam BLAST (2016). Untuk mendapatkan pohon filogenetiknya digunakan molecular evolutionary genetics analysis 5 (MEGA 5).

\section{Isolasi DNA total}

Isolasi DNA dilakukan dengan lisis mikroorganisme menggunakan metode lisis lisozim (Widodo \& Herdyastuti, 2014).

\section{Amplifikasi gen penyandi 16S-rRNA dengan PCR}

Amplifikasi gen 16S-rRNA dilakukan dengan menggunakan polymerase chain reaction (PCR). Untuk amplifikasi tersebut disiapkan master mix untuk setiap reaksi yang terdiri dari $5 \mu \mathrm{L}$ buffer PCR 10x ; 2 $\mu \mathrm{L}$ primer Uni B1 $5 \mu \mathrm{M} ; 2 \mu \mathrm{L}$ primer BactF $15 \mu \mathrm{M} ; 4 \mu \mathrm{L}$ dNTP (mix) $10 \mathrm{mM} ; 11,5 \mu \mathrm{L} \mathrm{MgSO}_{4} 70 \mathrm{mM} ; 0,5 \mu \mathrm{L}$ Taq HF DNA polymerase $5 \mathrm{U} / \mu \mathrm{L}$ dan $24,5 \mu \mathrm{L}$ aquabides. Pada master mix tersebut ditambahkan 2,5 $\mathrm{LL}$ DNA template sehingga total volume menjadi $50 \mu \mathrm{L}$. Kondisi reaksi PCR : siklus amplifikasi sebanyak 30 siklus dengan pre denaturasi pada suhu $95{ }^{\circ} \mathrm{C}$ selama 5 menit, denaturasi: $95^{\circ} \mathrm{C}$ selama 1 menit; annealing: $55^{\circ} \mathrm{C}$ selama 1 menit; elongasi: $72^{\circ} \mathrm{C}$ selama 1 menit dan post elongasi $72^{\circ} \mathrm{C}$ selama 10 menit (Widodo \& Herdyastuti, 2014).

\section{Verifikasi dengan elektroforesis gel agarosa}

Proses elektroforesis diawali dengan membuat gel agarose $1 \%$ yang disiapkan dengan menimbang 0,4 $\mathrm{g}$ agarose dan dilarutkan dalam $40 \mathrm{~mL}$ TBE $1 \mathrm{x}$ (Tris base, asam borat $85 \%$ dan $0,5 \mathrm{M} \mathrm{EDTA} \mathrm{pH} 8$ ) kemudian dilakukan elektroforesis (Widodo \& Herdyastuti, 2014).

\section{Elektroforesis dan Purifikasi hasil PCR}

Elektroforesis dilakukan dengan menggunakan gel agarosa $1 \%$ pada tegangan 100 Volt. Produk PCR target dengan ukuran sekitar 1500 bp dipurifikasi dengan QIAquick PCR purification kit (QIAGEN $\mathrm{GmbH}$, Germany). Tahapan purifikasi ini sangat penting untuk menghilangkan subtansi-subtansi seperti primer, nukleotida dan garam yang dapat mengganggu reaksi sekuen.

\section{Sequencing hasil PCR}

Produk PCR yang telah dipurifikasi, disekuen dengan menggunakan DNA sekuenser untuk mengetahui sekuen nukleotida dengan tepat (Hoda, 2008). Cycle sequencing dengan sequencer $A B I 310$ menggunakan reagen ABI PRISM Big Dye Terminator v 3.1 Cycle Sequencing Kit (Sanger, Donelson, Coulson, Kössel \& Fischer, 1974).

\section{HASIL DAN PEMBAHASAN}

\section{Penapisan bakteri lipolitik dari air limbah pengolahan hasil perikanan}

Hasil penapisan bakteri yang diisolasi dari air limbah pengolahan hasil perikanan yang ditumbuhkan pada media agar tributirin dan mempunyai kemampuan menghasilkan enzim lipolitik (lipase) berdasarkan zona bening dapat dilihat pada Tabel 1 dan Gambar 1.

Aktivitas bakteri dalam mendegradasi lemak atau bakteri lipolitik dalam air limbah pengolahan hasil perikanan, berhubungan erat dengan kemampuan bakteri tersebut dalam menghasilkan enzim lipase. Lipase (triasilgliserol lipase) adalah enzim yang dapat menghidrolisis trigliserol dan membebaskan asam lemak dan gliserol (Bestari \& Suharjono, 2015a). Salah satu parameter untuk penentuan bakteri lipolitik potensial adalah terbentuknya zona bening pada media agar tributirin yang terlihat jelas secara visual. Pembentukan zona bening pada setiap isolat sangat dipengaruhi oleh suhu dan $\mathrm{pH}$ selama pengujian. Selain itu, aktivitas ini juga dipengaruhi konsentrasi substrat dan enzim, serta adanya aktivator dan inhibitor (Yusufa, Padaga \& Octavianie, 2012).

Tabel 1 memperlihatkan bahwa isolat bakteri SKn, SPB, SOr dan SHj yang diisolasi dari industri pengolahan surimi memiliki zona bening yang lebih lebar dan berukuran lebih dari $6 \mathrm{~mm}$ dibandingkan dengan isolat lainnya. Konfirmasi terhadap luas zona bening keempat isolasi tersebut menunjukkan nilai yang konsisten. Diameter zona bening isolat SPB, SOr, SHj dan SKn berturut-turut adalah 24,0 0,9 ; $14,7 \pm 1,0 ; 11,3 \pm 1,6$ dan $18,0 \pm 1,5$. Keempat isolat ini dipilih untuk dilakukan identifikasi secara molekuler.

Dari penelitian sebelumnya diperoleh hasil bahwa kandungan lemak pada air limbah surimi sebesar 39,6 $\mathrm{mg} / \mathrm{L}$, dan pada air limbah pengalengan rajungan 
Tabel 1. Isolat bakteri pendegradasi lemak dari air limbah pengalengan rajungan di Cirebon (Jawa Barat) dan air limbah pengolahan surimi di Kendal (Jawa Tengah)

Table 1. Fat degrading bacteria isolated from crab canning wastewater in Cirebon (West Java) and surimi processing wastewater in Kendal (Central Java)

\begin{tabular}{|c|c|c|c|c|c|}
\hline $\begin{array}{c}\text { Kode } \\
\text { isolat/lsolate } \\
\text { Code }\end{array}$ & $\begin{array}{c}\text { Sumber air } \\
\text { limbah/Sources of } \\
\text { wastewater }\end{array}$ & $\begin{array}{c}\text { Warna dan bentuk } \\
\text { koloni/Colony color and } \\
\text { shape }\end{array}$ & $\begin{array}{l}\text { Diameter } \\
\text { koloni/Colony } \\
\text { diameter } \\
(\mathrm{mm})\end{array}$ & $\begin{array}{c}\text { Diameter zona } \\
\text { bening/Clear } \\
\text { zone diameter } \\
(\mathrm{mm})\end{array}$ & $\begin{array}{c}\text { Indeks } \\
\text { Lipolitik/ } \\
\text { Lipolytic } \\
\text { Index }\end{array}$ \\
\hline RGB & $\begin{array}{l}\text { Pengalengan daging } \\
\text { rajungan/(Swim crab meat } \\
\text { canning) }\end{array}$ & $\begin{array}{l}\text { Putih bulat/(White, } \\
\text { spherical) }\end{array}$ & 5 & 5.5 & 1.1 \\
\hline $\mathrm{RGBt}$ & $\begin{array}{l}\text { Pengalengan daging } \\
\text { rajungan/(Swim crab meat } \\
\text { canning) }\end{array}$ & $\begin{array}{l}\text { Putih tebal bulat/(Thick } \\
\text { w hite, spherical) }\end{array}$ & 4 & 4.5 & 1.1 \\
\hline RGKnt & $\begin{array}{l}\text { Pengalengan daging } \\
\text { rajungan/(Swim crab meat } \\
\text { canning })\end{array}$ & $\begin{array}{l}\text { Bulat kuning tipis (Thin } \\
\text { yellow spherical) }\end{array}$ & 4.5 & 5 & 1.1 \\
\hline RGBKn & $\begin{array}{l}\text { Pengalengan daging } \\
\text { rajungan/(Swim crab meat } \\
\text { canning) }\end{array}$ & $\begin{array}{l}\text { Bulat kuning/(Spherical, } \\
\text { yellow) }\end{array}$ & 3 & 4 & 1.3 \\
\hline RGBP & $\begin{array}{l}\text { Pengalengan daging } \\
\text { rajungan/(Swim crab meat } \\
\text { canning) }\end{array}$ & $\begin{array}{l}\text { Bulat putih/(Spherical, } \\
\text { white) }\end{array}$ & 3.5 & 4 & 1.1 \\
\hline sor & $\begin{array}{l}\text { Pengolahan surimi/(Surimi } \\
\text { processing) }\end{array}$ & $\begin{array}{l}\text { Bulat oranye/(Spherical, } \\
\text { orange) }\end{array}$ & 7.5 & 15.5 & 2.1 \\
\hline $\mathrm{SH}$ & $\begin{array}{l}\text { Pengolahan surimi/(Surimi } \\
\text { processing) }\end{array}$ & $\begin{array}{l}\text { Bulat hijau/(Spherical, } \\
\text { green) }\end{array}$ & 7.5 & 12.5 & 1.7 \\
\hline SKn & $\begin{array}{l}\text { Pengolahan surimi/(Surimi } \\
\text { processing) }\end{array}$ & $\begin{array}{l}\text { Bulat } \\
\text { kekuningan/(Spherical, } \\
\text { yellowish) }\end{array}$ & 7.5 & 19.5 & 2.6 \\
\hline SPB & $\begin{array}{l}\text { Pengolahan surimi/(Surimi } \\
\text { processing) }\end{array}$ & $\begin{array}{l}\text { Bulat putih/(Spherical, } \\
\text { white) }\end{array}$ & 9.5 & 23.5 & 2.5 \\
\hline $\mathrm{SBn}$ & $\begin{array}{l}\text { Pengolahan surimi/(Surimi } \\
\text { processing) }\end{array}$ & $\begin{array}{l}\text { Rhizoid, Bening/ } \\
\text { (Rhizoid,transparent) }\end{array}$ & 3 & 5.5 & 1.8 \\
\hline SKp & $\begin{array}{l}\text { Pengolahan surimi/(Surimi } \\
\text { processing) }\end{array}$ & $\begin{array}{l}\text { Bulat, kuning } \\
\text { pucat/(Spherical, pale } \\
\text { yellow) }\end{array}$ & 4 & 5 & 1.3 \\
\hline
\end{tabular}

kurang dari $1 \mathrm{mg} / \mathrm{L}$ (Oktavia \& Wibowo, 2012). Kandungan lemak pada air limbah surimi di Kendal tersebut telah melebihi ambang batas $10 \mathrm{mg} / \mathrm{L}$ yang ditetapkan oleh KEP-51/MENLH/10/1995 dan ambang batas $15 \mathrm{mg} / \mathrm{L}$ yang ditetapkan oleh Peraturan Pemerintah Nomor 6 Tahun 2007 tentang Baku Mutu Air Limbah Bagi Usaha dan/atau kegiatan Pengolahan Hasil Perikanan yang Melakukan Lebih dari Satu Jenis Kegiatan Pengolahan. Namun, kandungan lemak pada air limbah pengalengan rajungan di Cirebon masih di bawah ambang batas. Tingginya kandungan lemak pada air limbah surimi di Kendal tersebut diduga menjadi pendorong tumbuhnya bakteri lipolitik yang potensial dibandingkan air limbah pengalengan rajungan di Cirebon.

\section{Identifikasi bakteri secara molekuler}

Tahapan amplifikasi yang diuji dengan elektroforesis (Gambar 2), menghasilkan satu pita DNA 

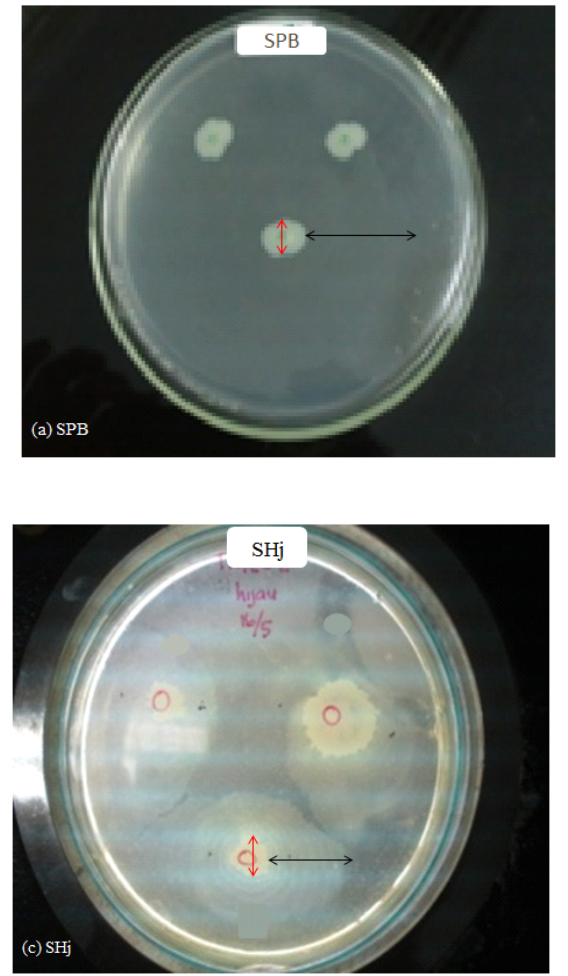
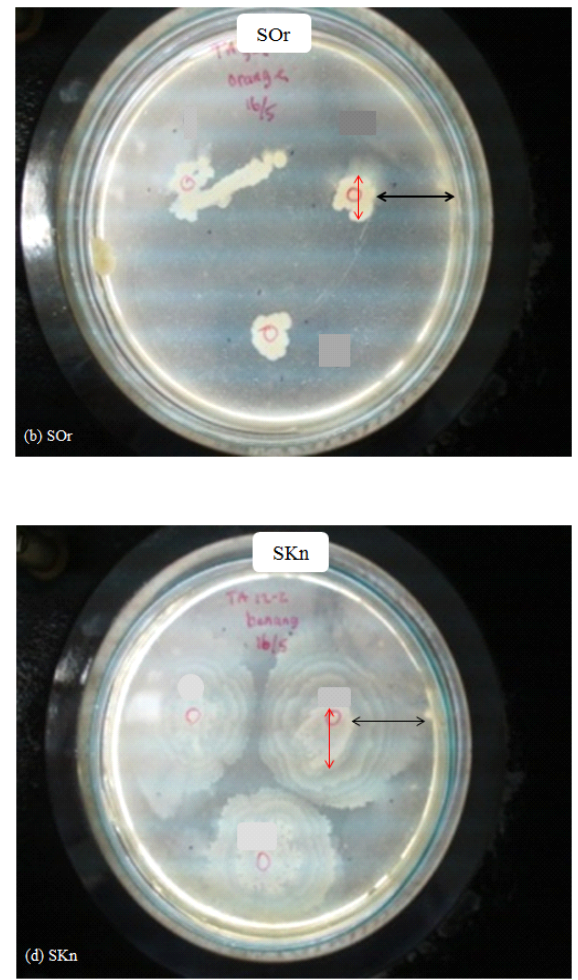

Keterangan :

$\longleftrightarrow$ diameter koloni

$\longleftrightarrow$ zona bening

Gambar 1. Zona bening yang dihasilkan oleh bakteri lipolitik yang diisolasi dari air limbah pengolahan surimi di Kendal (Jawa Tengah)

Figure 1. Clear zone of lipolytic bacteria from surimi processing wastewater in Kendal (Central Java)

dengan ketebalan yang relatif sama. Primer $16 \mathrm{~S}$ digunakan untuk identifikasi gen 16S-rRNA bakteri. Menurut Pangastuti (2006), DNA pengkode gen 16SrRNA digunakan untuk menentukan genus dan strainnya. DNA pengkode 16S-rRNA dapat digunakan sebagai penanda molekuler untuk definisi spesies karena gen ini ada pada setiap organisme dengan fungsi yang identik. Terlihat pada Gambar 2 bahwa gen 16S-rRNA teridentifikasi pada isolat bakteri pendegradasi lemak terseleksi yang diamplifikasi menggunakan primer $16 \mathrm{~S}$.

Hasil identifikasi isolat bakteri dari air limbah pengolahan surimi tampak seperti di dalam Tabel 2 sedangkan pohon filogenetiknya disajikan pada Gambar 3. Berdasarkan hasil sekuen gen 16S-rRNA yang didasarkan pada urutan nukleotida dari gen 16SrRNA dan dibandingkan dengan data gen 16S-rRNA yang tersedia di Genbank (BLAST, 2016), isolat SPB teridentifikasi sebagai Serratia fonticola 10A dengan kemiripan $97 \%$. Sekuen gen 16S-rRNA bakteri ini yang diamplifikasi mempunyai panjang basa $1310 \mathrm{bp}$ dengan nilai E-value 0. Nilai E-value yang dihasilkan pada Tabel 2 bernilai 0 yang artinya isolat identik dengan spesies pembandingnya. Nilai kemiripan sebesar 97\% mengindikasikan bahwa isolat SPB dan Serratia fonticola 10A dianggap sebagai spesies yang sama. Hagstrom Pinhasi dan Zweifel (2000) menyatakan bahwa bakteri yang mempunyai persamaan sekuen 16S-rRNA lebih besar dari 97\% adalah spesies yang sama, sedangkan persamaan sekuen antara 93-97\% dapat mewakili identitas pada tingkat genus tetapi berbeda pada tingkat spesies. $S$. fonticola dilaporkan sebagai spesies baru oleh Gavini et al. (1979). Dinyatakan bahwa bakteri ini bersifat Gram negatif, dan berbentuk batang pendek (rod). Menurut Grimont dan Grimont (2006) Serratia merupakan bakteri yang termasuk ke dalam famili Enterobacteriaceae, mampu menghasilkan enzim kitinase, proteinase, gelatinase dan lipase dan umumnya patogen. Penggunaan $S$. fonticola yang diisolasi dari keluaran industri bioteknologi mampu 


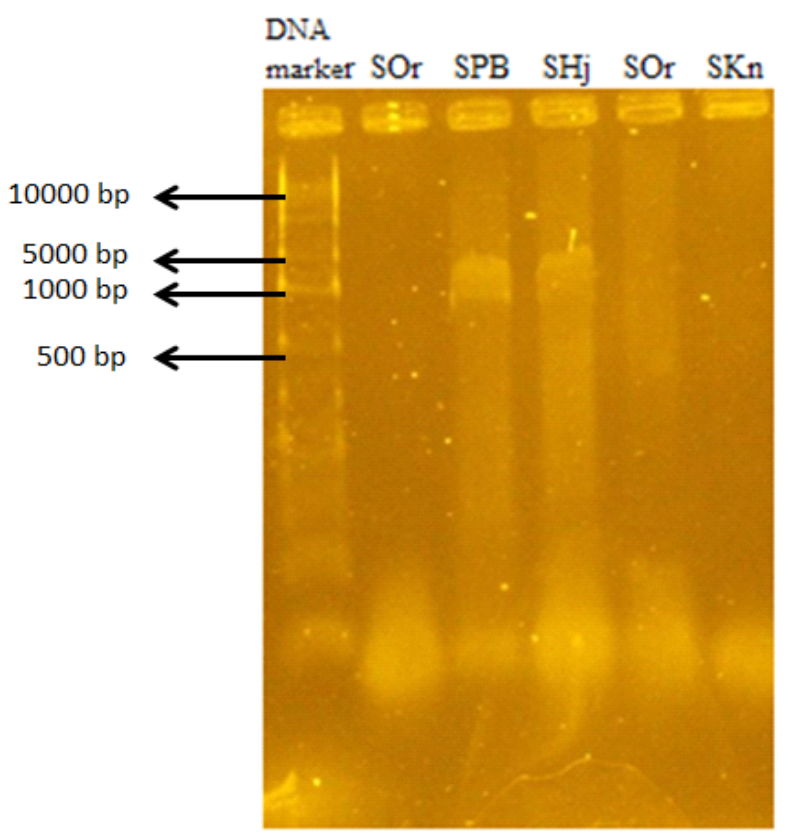

Gambar 2. Elektroferogram hasil amplifikasi gen 16S-rRNA pada bakteri lipolitik yang diuji

Figure 2. Elektroferograms of amplification result of the 16S-rRNA gene in lipolytic bacteria tested

mengemulsi $2 \%$ minyak kedelai selama 10 hari (Facchin et al., 2013). Selain itu, Raicevic et al. (2010) melaporkan bahwa $S$. fonticola bersama-sama dengan Pseudomonas dan Bacillus menunjukkan efisiensi yang tinggi dalam mereduksi Kromium (VI) pada bioremediasi bekas tambang bauksit.

Hasil identifikasi molekuler isolat SOr menunjukkan homologi $96 \%$ dengan Bacillus pumilus strain vit bac1. Gen 16S-rRNA yang diamplifikasi ini mempunyai panjang basa 1262 bp dan nilai E-value 0 . Nilai $E$-value merupakan nilai dugaan yang memberikan ukuran statistik yang signifikan terhadap kedua sekuen. Nilai E-value yang semakin tinggi menunjukkan tingkat homologi antar sekuens semakin rendah, sedangkan nilai E-value yang semakin rendah menunjukkan tingkat homologi antar sekuens semakin tinggi. Nilai E-value bernilai 0 (nol) menunjukkan bahwa kedua sekuens tersebut identik (Claverie \& Notredame, 2003). B. pumilus merupakan bakteri Gram positif yang bersifat aerob pembentuk spora yang umumnya ditemukan di tanah. Mi-Hwa et al. (2013) melaporkan bahwa $B$. pumilus yang diisolasi dari makanan tradisional Korea yaitu pasta kacang kedelai yang difermentasi merupakan bakteri lipolitik,

Tabel 2. Hasil identifikasi isolat bakteri SPB, SOr, SHj dan SKn

Table 2. Identification on SPB, SOr, SHj and SKn bacteria isolates

\begin{tabular}{clccc}
\hline $\begin{array}{c}\text { Kode } \\
\text { isolat/solate } \\
\text { code }\end{array}$ & $\begin{array}{c}\text { Hasil } \\
\text { Identifikasi/Identification } \\
\text { result }\end{array}$ & $\begin{array}{c}\text { Kemiripan/ } \\
\text { Similarity (\%) }\end{array}$ & E-value/E-value & $\begin{array}{c}\text { Nomor } \\
\text { Akses/Access } \\
\text { number }\end{array}$ \\
\hline SPB & Serratia fonticola 10A & 97 & 0,0 & LT555292.1 \\
SOr & $\begin{array}{l}\text { Bacillus pumilus strain vit } \\
\text { bac1 }\end{array}$ & 96 & 0,0 & $\mathrm{KC} 845305.1$ \\
$\mathrm{SHJ}$ & $\begin{array}{l}\text { Bacillus cereus strain } \\
\text { 103.2.2 }\end{array}$ & 97 & 0,0 & $\mathrm{KX} 453862.1$ \\
$\mathrm{SKn}$ & $\begin{array}{l}\text { Enterococcus } \\
\text { pseudoavium strain }\end{array}$ & 87 & 0,0 & $\mathrm{KU} 311979.1$ \\
\hline
\end{tabular}




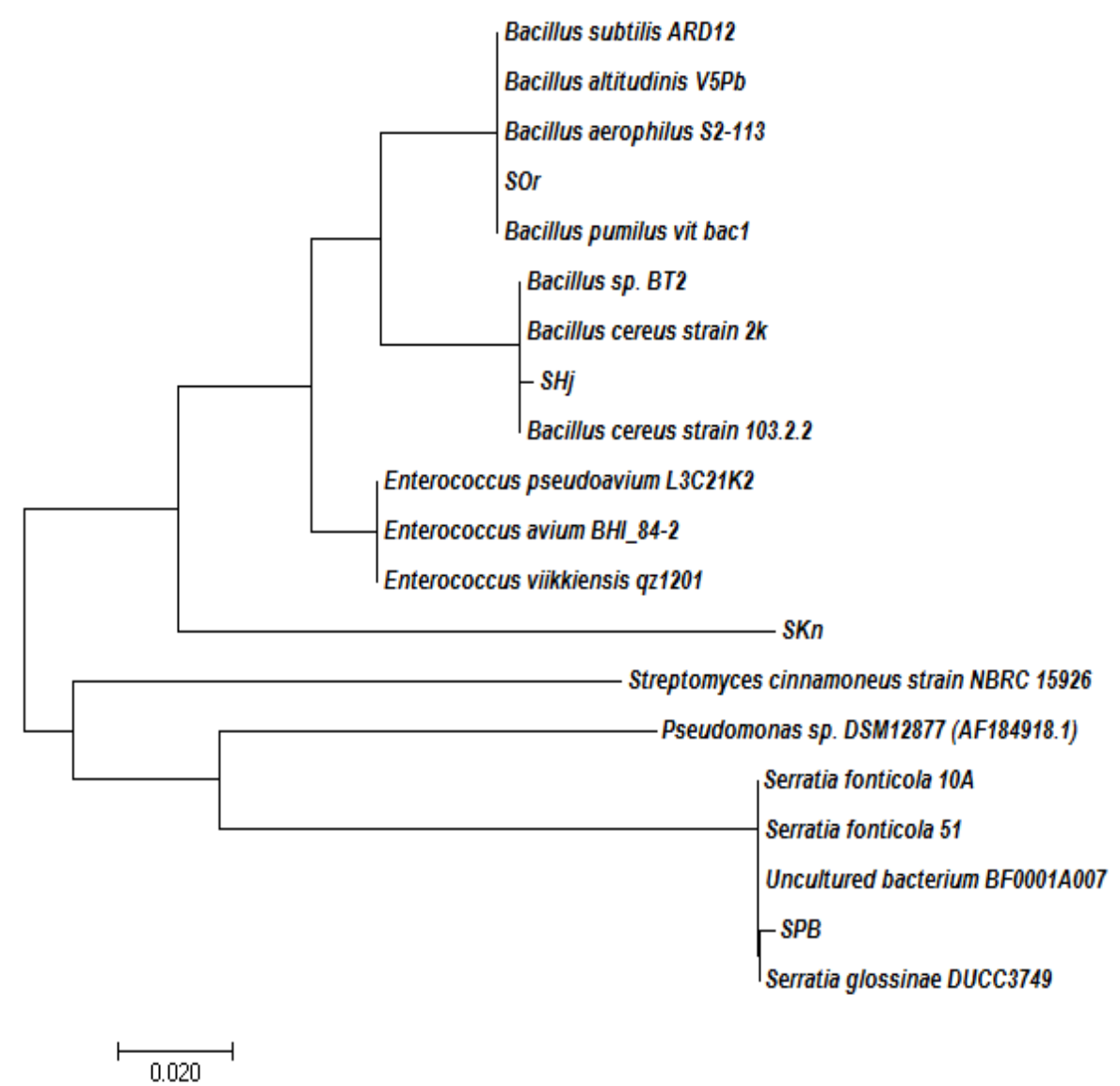

Gambar 3. Pohon filogenetik isolat SPB, SOr, SHj dan SKn

Figure 3. The phylogenetic tree of bacterial isolates of SPB, SOr, SHj and SKn

yang mempunyai aktifitas lipase sebesar $140 \mathrm{U} / \mathrm{mL}$ pada akhir fase eksponensial. Konsorsium bakteri yang mengandung $B$. pumilus mempunyai efektifitas menurunkan BOD $71,93 \%$, COD $64,30 \%$, TSS $94,85 \%$ dan amonia $88,58 \%$ pada proses bioremediasi di Instalasi Pengolahan Air Limbah (IPAL) Cisirung, Bandung Selatan (Safitri, Priadie, Miranti \& Astuti, 2015).

Isolat $\mathrm{SHj}$ memiliki kekerabatan paling dekat dengan Bacillus cereus 103.2.2. Gen 16S-rRNA yang diamplifikasi memiliki panjang basa 1293 bp dan Evalue 0,0 . Skala 0,02 menunjukkan jarak evolusi pada panjang cabang. Montanhini, Montanhini, Pinto \& Bersot (2013) melaporkan bahwa $B$. cereus yang diisolasi dari produk susu mempunyai aktifitas lipolitik dan proteolitik. Sebanyak 16,3\% strain memproduksi lipase pada suhu $10{ }^{\circ} \mathrm{C}$, hanya 1 strain yang menghasilkan lipase pada suhu $30^{\circ} \mathrm{C}$. Nabrdalik, Grata dan Latala (2008) melaporkan bahwa biosintesis lipase ekstraseluler yang paling efektif berasal dari substrat lemak tributirin pada kasus semua strain. Strain Bacillus cereus G10 membebaskan asam lemak tertinggi sebesar $97,5 \mu \mathrm{mol}$, sedangkan asam lemak terendah dibebaskan oleh strain Bacillus pumilus Tw3 sebesar 13,125 $\mu \mathrm{mol}$.

Hasil identifikasi molekuler, isolat SKn memiliki tingkat kemiripan $87 \%$ dengan Enterococcus pseudoavium strain L3C21K2 dan gen 16S-rRNA yang diamplifikasi ini mempunyai panjang basa 978 bp dan E-value sebesar 0,0 (Tabel 3). Namun dalam pohon filogenetik (Gambar 3) SKn tidak menunjukkan kedekatan dengan Enterococcus. Hal ini kemungkinan disebabkan karena panjang basa (978 bp) yang kecil (Uria, komunikasi pribadi, Oktober 2016). Enterococcus merupakan bakteri Gram positif yang bersifat fakultatif anaerob dengan kondisi suhu $10-45^{\circ} \mathrm{C}$ serta $\mathrm{pH} 4,5-10$. Oleh karena itu isolat SKn diduga sebagai bakteri spesies baru dari Enterococcus. 

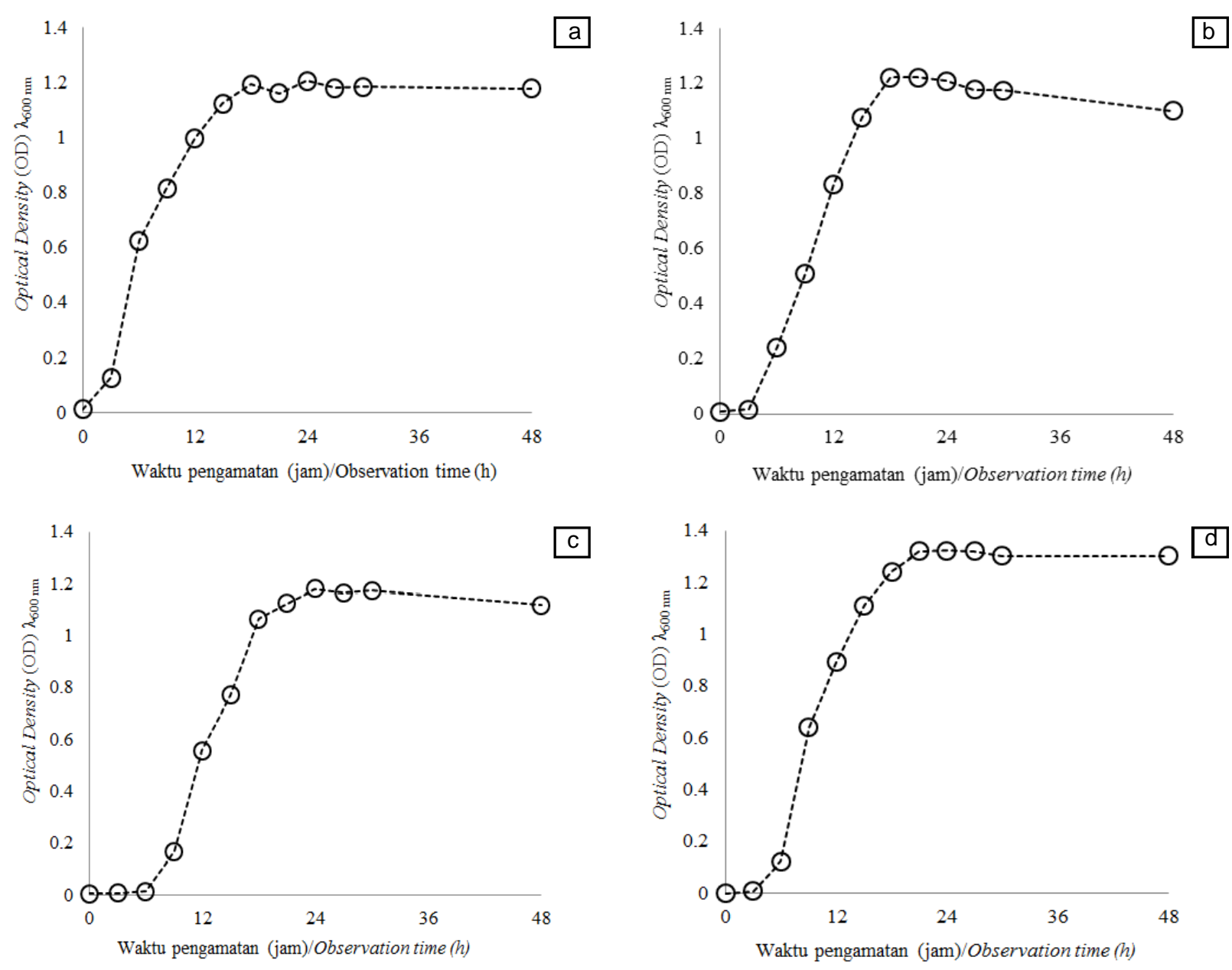

Gambar 4. Kurva pertumbuhan isolat bakteri lipolitik a) SPB, b) SOr, c) SHj dan d) SKn

Figure 4. Growth curve of lipolytic bacteria isolates of a) $S P B$, b) $S O r, c) S H j$ and d) $S K n$

\section{Pertumbuhan isolat bakteri lipolitik SPB, SOr, SHj dan SKn}

Kurva pertumbuhan isolat bakteri SPB, SOr, $\mathrm{SHj}$ dan SKn disajikan pada Gambar 4. Kurva ini diperlukan untuk mengetahui kondisi pertumbuhan optimum tiap isolat yang akan digunakan sebagai starter konsorsium bioremedian, karena penambahan isolat dilakukan pada saat fase logaritmik (Chowdhury Thakur \& Chaudhuri, 2011). Dari pengamatan pertumbuhan keempat bakteri tersebut, bakteri SPB mempunyai nilai optical density (OD) tertinggi sebesar 1,19 pada jam ke-18. Fase stasioner bakteri SPB terjadi pada jam ke-24 yang mempunyai nilai OD sebesar 1,21 hingga jam ke-48 (Gambar 4). Khleifat (2006) melakukan pengukuran kurva pertumbuhan konsorsium bakteri pada media nutrient broth (NB) dan minimal media (MM) sebagai starter dan digunakan sebagai verifikator degradasi linear alkylbenzene sulfonate (LAS). Konsorsium bakteri terdiri dari Pantoea agglomerans dan Serratia odorifera 2 yang diisolasi dari instalasi pengolahan limbah. Persentase degradasi LAS 200 ppm menggunakan konsorsium bakteri lebih baik saat mikroba ditumbuhkan pada media nutrient broth ( 70\%) dibandingkan minimal media (36\%), sedangkan kemampuan degradasi LAS oleh konsorsium bakteri lebih tinggi daripada isolat tunggal.

Menurut Bestari dan Suharjono (2015b), aktivitas lipolitik kemungkinan menjadi bagian dari aktivitas metabolit primer bakteri yang terjadi dengan mengikuti fase pertumbuhan mikroba, yaitu meningkat optimum pada akhir fase logaritmik atau awal fase stasioner kemudian menurun seiring dengan aktivitas mikroba dan penurunan nutrisi substrat. Isolat SOr dan SKn mempunyai awal fase logaritmik lebih cepat daripada isolat SPB dan SHj. Pada jam ke-3 isolat SOr memiliki $\mathrm{OD}_{600}$ sebesar 0,02 dan isolat $\mathrm{SKn}$ sebesar 0,01 (Gambar 4). Awal fase logaritmik isolat SHj baru terjadi pada jam ke-9. Pada akhir fase logaritmik isolat SKn 
mempunyai nilai $\mathrm{OD}_{600}$ yang lebih tinggi dibandingkan dengan isolat lainnya yaitu sebesar 1,32. Fase stasioner isolat SKn, SOr dan SPB dimulai pada jam ke-18 sedangkan isolat $\mathrm{SHj}$ dimulai pada jam ke-24.

Aktivitas lipase sangat dipengaruhi oleh jenis mikroba, substrat, konsentrasi, suhu, serta waktu inkubasi yang berhubungan dengan fase pertumbuhan mikroba. Aktivitas lipase pada masing-masing isolat dapat berbeda pada setiap fase dan pada setiap waktu inkubasi (Bestari \& Suharjono, 2015a). Monod (1949) menjelaskan bahwa laju pertumbuhan tergantung pada energi dan subtrat karbon yang besarnya bervariasi sesuai kondisi lingkungan seperti suhu, $\mathrm{pH}$ dan ketersediaan nutrien. Berdasarkan kurva pertumbuhan di atas, penggunaan keempat isolat sebagai bioremedian dilakukan ketika pertumbuhan berada pada fase logaritmik sebelum mulai stasioner, yaitu untuk isolat SPB ditumbuhkan selama 6-15 jam, isolat SOr selama 9-15 jam, isolat $\mathrm{SHj}$ selama 12-15 jam dan isolat SKn ditumbuhkan selama 9-18 jam.

\section{KESIMPULAN}

Telah diperoleh empat isolat bakteri lipolitik yang mempunyai zona bening lebih dari $6 \mathrm{~mm}$ yaitu isolat SPB dengan zona bening $23,5 \mathrm{~mm}$, isolat SKn 19,5 $\mathrm{mm}$, isolat SOr $15,5 \mathrm{~mm}$ dan isolat SHj $12,5 \mathrm{~mm}$. Berdasarkan analisis sekuen 16S-rDNA masingmasing isolat SPB dan SHj memiliki kemiripan 97\% dengan Serratia fonticola 10A dan Bacillus cereus strain 103.2.2, sedangkan isolat SOr memiliki kemiripan $96 \%$ dengan Bacillus pumilus strain vit bac1 dan isolat SKn memiliki kemiripan $87 \%$ dengan Enterococcus pseudoavium strain L3C21K2.

\section{DAFTAR PUSTAKA}

Ankit, M., Yaginik, S. K., Pranali, M., \& Yadav, S. K. (2011). Screening and Temperature Optimization for LipaseProducing Bacteria from Waste Contaminated Water. Asian Journal of Biochemical and Pharmaceutical Research, 1(1), 62-69.

Bestari, N. C., \& Suharjono. (2015a). Uji Kualitatif dan Kuantitatif Isolat Bakteri Lipolitik dari Limbah Cair Pabrik Pengolahan Ikan Kecamatan Muncar, Banyuwangi. Jurnal Biotropika, 3(3), 151-155.

Bestari, N. C., \& Suharjono. (2015b). Activity Assay and Identification of Lipolytic Bacteria from Wastewater Fish Industry at District Muncar, Banyuwangi Indonesia. International Journal of ChemTech Research, 8(11), 377-383.

Bhumibhamon, O., Koprasertsak, A., \& Funthong, S. (2002). Biotreatment of high fat and oil wastewater by lipase producing microorganisms. Kasetsart J., (Nat Sci)., 36, 261-267.
[BLAST]. Basic Local Alignment Search Tool. 2016.https:/ /blast.ncbi.nlm.nih.gov/Blast.cgi

Chowdhury, S., Thakur, A. R., \& Chaudhuri, S. R. (2011). Novel microbial consortium for laboratory scale lead removal from city effluent. J. Environment Sci. Technol., 4(1), 41-54.

Claverie, J. M., \& Notredame, C. (2003). Bioinformatics for Dummies. Indianapolis : Wiley Publishing. p 480

Colic, M., Morse, W., Hicks, J., Lechter, A., \& Miller, J.D. (2011). Case study : Fish processing plant wastewater treatment. Clean Water Technology, Inc. Goleta, CA.

Darmayasa, I. B. G. (2008). Isolasi dan identifikasi bakteri pendegradasi lipid (lemak) pada beberapa tempat pembuangan limbah dan estuari DAM Denpasar. $J$ Bumi Lestari 8 (2) :122-127.

Facchin, S., Alves, P. D. D., Siqueira, F. d. F., Barroca, T. M., Victória, J. M. N., \& Kalapothakis, E. (2013). Biodiversity and Secretion of Enzymes with Potential Utility in Wastewater Treatment. Open Journal of Ecology, 3(1), 34-47.

Gavini, F., Ferragut, C., Izard, D., Trinel, P. A., Leclerc, H., Lefebvre, H. \& Mossel, D.A.A. (1979). Serratia fonticola, a New Species from Water. International Journal of Systematic Bacteriology, 2, 92-101.

Grimont, F., \& Grimont, P. A. D. (2006). The Genus Serratia. Chapter 3.3.11. The Prokaryotes. A Handbook on the Biology of Bacteria. Third Edition, Volume 6: Proteobacteria: Gamma Subclass (Eds : Dworkin, M., Falkow, S., Rosenberg, E., Schleifer, KH., Stackebrandt, E.). Springer.New York. USA. p 219244 DOI :10.1007/0-387-30746-x_11.

Hagstrom, A. J. F., Pinhasi, \& Zweifel, U. L., (2000). Biogeographycal diversity among marine bacterioplankton. Aqua Microbiol. Technol., 21, 231244.

Hoda, A. (2008). Studi Karakterisasi, Produktivitas dan Dinamika Populasi Kambing Kacang (Capra hircus) untuk Program Pemuliaan Ternak Kambing di Maluku Utara. Disertasi. Institut Pertanian Bogor. p 203.

Hidayat, N. (2011). Optimization of $\mathrm{pH}$, Temperature and Agitation Rate on Biodegradation of Lipids and Detergents in Food Wastewater by Bacillus sp N-09. J. Agric. Food Tech., 1(5), 59-62.

Mongkolthanaruk, W., \& Dharmsthiti, S. (2002). Biodegradation of lipid-rich wastewater by a mixed bacterial consortium. Int. Biodeteriorat. \& Biodegrad. 50, 101-105.

Monod, J. (1949). The growth of bacterial cultures. Annu. Rev. Microbiol., 3, 371-394.

Nabrdalik, M., Grata, K., \& Latala, A. (2008). Evaluation of Lipolytic Activity of Bacillus sp. Isolated from The Natural Environment. Proceeding of ECOpole, 2(2), 359-362.

Khleifat, K. M. (2006). Biodegradation of Linear Alkylbenzene Sulfonate by a Two-Member Facultative Anaerobic Bacterial Consortium. Enzyme and Microbial Technol., 39,1030-1035.

Loperena, L., Ferrari, M. D., Diaz, A. L., Ingold, G., Perez, L.V., Carvallo, F., Travers, D., Menes, R.J., \& Lareo, C. 
(2009).Isolation and selection of native microorganisms for the aerobic treatment of stimulated dairy wastewaters. Bioresource Technol., 100, 1762-1766.

Mi-Hwa, L., Song, J. J., Choi, Y. H., Hong, S. P., Rha, E., Kim, H.K., Lee, S. G., Poo, H., Lee, S.C., Seu, Y.B., \& Sung, M.H. (2013). High-Level Expression and Secretion of Bacillus pumilus Lipase B26 in Bacillus subtilis Chungkookjang. J. Microbiol. Biotechnol. 13(6), 892-896.

Montanhini, M. T. M., Montanhini, R.N., Pinto, J. P. N., \& Bersot, L. S. (2013). Effect of temperature on the lipolytic and proteolytic activity of Bacillus cereus isolated from dairy products. International Food Research Journal, 20(3),1417-1420.

Oktavia, D. A., \& Wibowo, S. (2012). Degradasi Kadar Protein dan Lemak pada Limbah Cair Industri Pengolahan Produk Perikanan dengan Penambahan Isolat Mikroba. Prosiding Masyarakat Pengolahan Hasil Perikanan Indonesia (MPHPI), 1-11.

Oktavia, D. A. (2011). Data belum dipublikasi.

Pangastuti, A. (2006). Review : Definisi Spesies Prokaryota Berdasarkan Urutan Basa Gen Penyandi 16s rRNA dan Gen Penyandi Protein. Biodiversitas. 7(3), 292-296.

Prasad, M. P., \& Manjunath, K. (2011). Comparative study on biodegradation of lipid-rich wastewater using lipase producing bacterial species. Indian Biotechnol., 10, 121-124.

Raicevic, V., Golic, Z., Lalevic, B., Jovanovic, L., Kikovic, D., \& Mladenovic, S.A.(2010). Isolation of Chromium Resistant Bacteria from a Former Bauxit Mine Area and Their Capacity for $\mathrm{Cr}(\mathrm{VI})$ Reduction. African J. of Biotechnology, 9(40), 6727-6732.

Renjana, E., Ni'matuzahroh, \& Sumarsih, S. (2012). Skrining dan uji aktivitas lipolitik bakteri hidrokarbonoklastik. Diakses tanggal 17 Sept. 2012 h t t p : / / d o wn load.portalgaruda.org / article.php?article $=17995 \& \mathrm{val}=1125$

Safitri, R., Priadie, B., Miranti, M., \& Astuti, A.W. (2015). Ability of Bacterial Consortium: Bacillus coagulans, Bacilus licheniformis, Bacillus pumilus, Bacillus subtilis, Nitrosomonas sp. and Pseudomonas putida in Bioremediation of Waste Water in Cisirung Waste Water Treatment Plant. AgroLife

Sanger, F., Donelson, J. E., Coulson, A. R., Kössel, H., \& Fischer, D. (1974). Determination of a Nucleotide Sequence in Bacteriophage $\mathrm{f} 1$ DNA by Primed Synthesis with DNA Polymerase. J Mol Biol., 90(2): 315-33.

Setiyono, \& Wahjono, H. D. (2006). Pengelolaan Limbah Kawasan Industri Kecil di Kota Tegal. JAI., 2(2): 139148.

Setiyono, \& Yudo, S. (2008). Dampak Pencemaran Lingkungan akibat Limbah Industri Pengolahan Ikan di Muncar (Studi Kasus Kawasan Industri Pengolahan Ikan di Muncar-Banyuwangi). JAl., 4(1), 69-80.

Sirisha, E., Rajasekar, N., \& Narasu, M. L. (2010). Isolation and optimization of lipase producing bacteria from oil contaminated soils. Advances in Biological Research, 4(5), 249-252.

Suwanto, A., Yogiara, Suryanto, D., Tan, I., \& Puspitasari, E. (2000). Selected protocols. Training Course on Advances in Molecular Biology Techniques to Asses Microbial Diversity. BIOTROP. Bogor. $28 \mathrm{pp}$.

Tay, J. H., Show, K. Y., \& Hung, Y. T. (2006). Seafood processing wastewater treatment. Taylor \& Francis Group, LLC.

Wahyuntari, B., Mubarik, N. R., \& Anggarani, M. (2004). Isolation and selection of alkaline proteolytic bacteria from leather processing waste and enzyme characterization. Biotropia, 22, 29-39.

Widodo, R., \& Herdyastuti. (2014). Penentuan Gen Penyandi 16S-rRNA Bakteri Kitinolitik dari Tambak Udang Lamongan. UNESA Journal of Chemistry, 3(1), 85-88.

Yusufa, M. H., Padaga, M. C., \& Octavianie, D. A. (2012). Identifikasi dan Studi Aktivitas Protease Bacillus sp. asal Limbah Cair Rumah Potong Ayam Tradisional sebagai Kandidat Penghasil Biodeterjen. Diakses tanggal 4 Februari 2016. http://fkh.ub.ac.id/wpcontent/uploads/2012/10/0811310028-M.-HartantoYusufa.pdf 